KATARZYNA ZADROS

\title{
The assessment of medical subject mamagers' knowledge on topic of social responsibility
}

\section{Introduction}

In the 1980s and 1990s the organization and management of public sector institutions underwent restructuring. Reforms undertaken by numerous countries, including Poland, disturbed the previous conditions and principles that had regulated the functioning of this sector. Due to system changes and the introduction of market mechanisms and competition, management methods in public sector institutions became similar to the methods that are typical for business organizations.

This situation concerns, among others, health care institutions. State health care has become a purely historical entity, replaced by independent public institutions providing health care services and non-public health care institutions, which compete with one another on equal terms. That is why the need to compete for patients and financial resources, that are necessary to run the institution, has led to numerous changes in the management and functioning of public health care institutions.

What follows is that patients are more and

Ph.D. Katarzyna Zadros Czestochowa University of Technology more aware of their rights and they have higher and higher expectations as for the quality of 
the provided services, and the professionalism of health care institutions and providers. Thus nobody is surprised by introducing ISO norms and quality management in health care institutions, or by widespread acceptation of codes of conduct concerning the performance of specific medical procedures. However, the implementation of modern management tools into the activity of health care institutions still seems highly insufficient; these are especially such tools that enable the cooperation of the institutions with other institutions and stakeholders in order to meet the needs of the community to which they provide their services.

The author suggests that one of the methods that are practically unknown, despite their high usefulness, is the concept of the social responsibility of an organization. Therefore, in the study presented below, an attempt will be made to diagnose the knowledge of health care managers on the subject of this concept and the possibility of using it in managing medical subjects.

\section{Theoretical aspects of creating corporate social responsibility in health care institutions}

The concept of corporate social responsibility (CSR) is an assumption that organizations will conduct their activities and, at the same time, they will voluntarily take into account social interests, protection of the environment and relations with widely understood stakeholders. This is an approach with a strategic dimension, a dynamic character and one that concerns "a proper conduct which results from decisions aimed at keeping the balance among the interests of all sides." (Rok 2001, p. 195)

All activities connected with implementing CSR can be divided into those that are directed outside the institution and those directed inside. (Sudoł 2006, p. 72). The most common inside activities are: actively supporting employees' health and well-being, giving the possibility to practice and get professional experience, respecting employees' rights and eliminating employment discrimination. (Kusa 2010; Hąbek, Pawłowska 2009 p. 18.) Outside responsibility in turn includes: the attitude to investors, customers, authorities, protecting natural environment, cooperation with local circles. (Rojek-Nowosielska 2006, p. 68).

"Initiating activities connected with corporate social responsibility in an organization is the duty of the management staff, who represent the company outside and organize and coordinate its functioning inside. Their knowledge (...) as well as technical, conceptual and social skills can significantly increase the employees' involvement, thus allowing for effective implementation of 
the concept of corporate social responsibility." (Hąbek, Pawłowska 2009, s. 19.) Another field of activity connected with implementing CSR by the management staff should be including this concept in the organization's development strategy as well as building reputation and trust in the organization, which is especially important for medical institutions. Thus it seems legitimate to claim that, in case of health care institutions, social responsibility is "rooted in the very nature and mission of the organizations (...) so it is especially important for them (...) to underline the social character of their activity and to cooperate with recipients of their services as actively as possible" (Program ..., 2006, p. 12).

One must also pay attention to the fact that social responsibility in the health care sector is perceived as a holistic approach that is based on "extensive and universal processes; its basis is constituted by personal responsibility towards users and customers; it is an approach that takes into account values and the awareness of values, such as clarity, involvement and partnership. Social responsibility in the health care sector (...) depends on equipping it with social innovations through strategic partnership and a stakeholder-oriented attitude; it depends on measuring the value added, promoting professionalism and supporting social changes that lead to long-term development of the organization and personal development of beneficiaries "(Program ..., 2006, s. 24).

One can say that it is a process of the organization's constant and gradual improvement which helps the organization to meet the demands of the present and future more and more efficiently, and where constant dialogue with stakeholders plays a key role. Furthermore, in case of health care institutions, the nature of the organizations makes social responsibility not only desired, but simply indispensible to realize their duties and mission. Researchers claim, however, that despite evident benefits that result from using this concept in management, the general level of knowledge about social responsibility among the managing staff and employees is poor. J. Filek divided the lack of knowledge in this area into six categories: terminological, economical, factual, philosophical, historical and ethical. (Filek 2008, p. 69). This lack of knowledge is directly related to "the question of a wrong interpretation of social expectations or a lack thereof." (Hąbek, Pawłowska 2009, p. 19.) And this leads to creating myths and wrong interpretations of both the very concept and the activities that can be labeled as socially responsible. This in turn causes an unwillingness to introduce CSR in organizations and a distrust in its positive effects.

In addition, as pointed out by M. Żemigała (2007, p. 20),, introducing the concept of social responsibility, paradoxically, leads to a high probability of 
rapidly increased costs connected with running the organization, which results from the need to invest in human resources and relations with shareholders.

Therefore, there is the question whether management staff in health care institutions are interested in practical application of this concept in management, and to what extent management solutions used by managers allow for introducing CSR principles into the activity of the institutions. In what follows, the author attempts to address these questions.

\section{Methodological assumptions of the research}

The aim of the research was to determine the knowledge that managers of health institution have about CSR, and to find out which of their activities can be labeled as socially responsible. The object of the research were the managers' opinions about applying social responsibility in relations with their employees and outside stakeholders. The author selected managers of public and non-public institutions that have concluded a contract with the NFZ (National Health Fund) and operate in the Silesian voivodeship (province).

The research problem was the following: What is the managers' level of knowledge and what is the actual state of socially responsible practices in the activity of health care institutions. To address the problem, the author attempted to obtain information by asking a series of more specific questions:

1. What do management staff members of health care institution know about CSR?

2. According to the managers, do they and their employees act in a socially responsible way?

3. How do they cooperate with stakeholders, and who do they consider to be the stakeholders?

4. How does the organization try to provide the best quality services adequate to social needs and expectations?

The assumptions allowed to form the hypothesis that: managers lack knowledge and interest when it comes to introducing and respecting the principles of social responsibility in the health care institutions that they manage.

To verify the research assumptions, the author used the diagnostics survey method, with an anonymous questionnaire as the technique. Composing the questionnaire as a research tool was inspired by questionnaires created by R. Walkowiak M. Oliński, M. Wysocka, M. Adamowicz (2010, p. 25). The questionnaire was sent by e-mail to health care institutions in the Silesian voivodeship. The survey was carried out in November and December 2013. 
The request to participate in the survey was sent to 1420 institutions that have concluded a contract with the NFZ. By the end of December the author received 348 filled-in questionnaires and they are the basis for further analysis.

\section{The analysis of research results}

The survey started with a question determining the managers' level of knowledge about CSR. Regardless of the kind of institution and its legal and organizational status, it became clear that the level of knowledge is extremely low: as many as 288 respondents do not know the concept at all and have never heard about it. Only 13 respondents know the concept and principles of CSR very well. Others have poor knowledge or know just the term (fig.1).

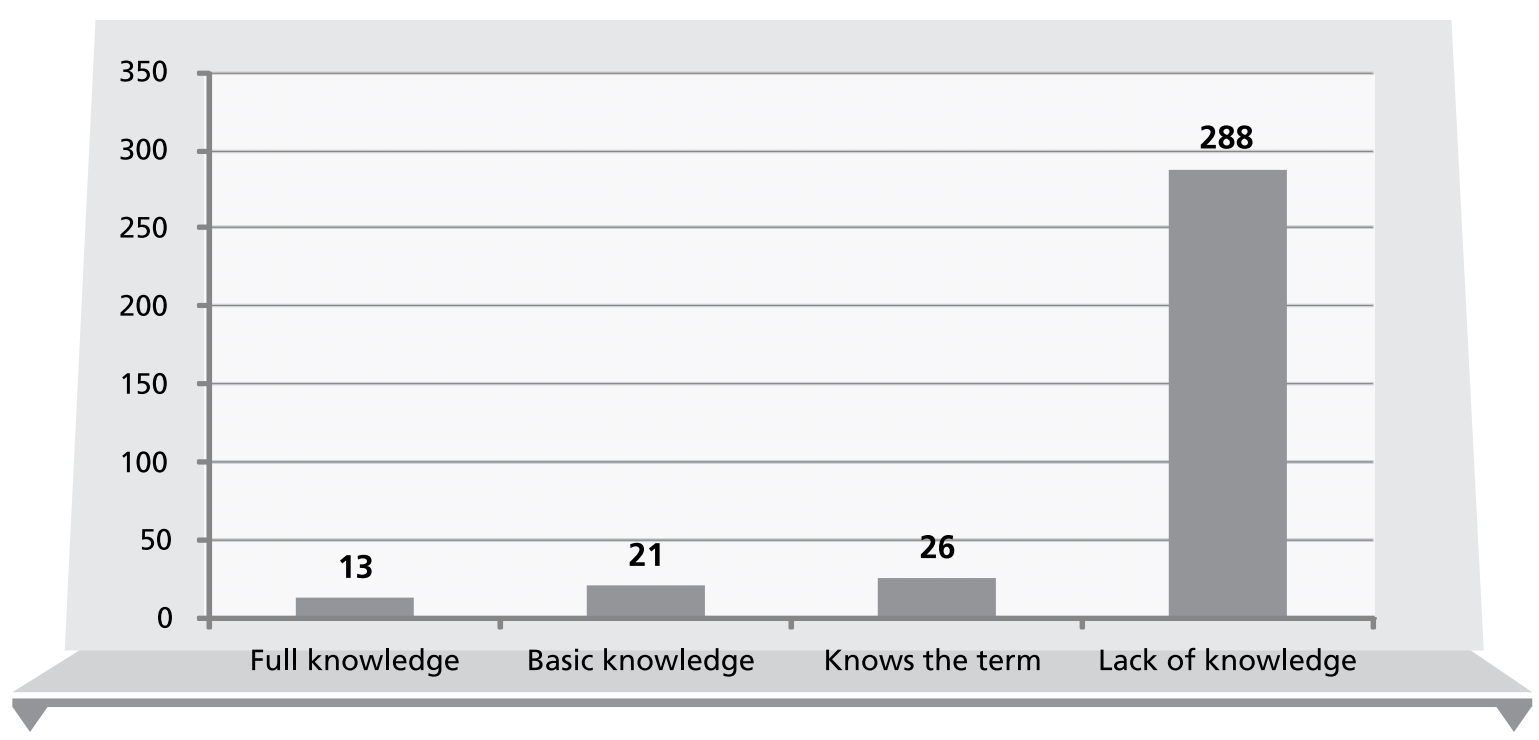

Figure 1. Managers' knowledge about CSR

Source: own elaboration based on a questionnaire survey

This unfavourable distribution of responses does not necessarily mean that health care institutions and their managers do not act socially responsibly. It seems highly possible that their activities are based on ethical standards but they are not commonly identified with the principles of social responsibility.

As it was expected that the level of knowledge could be relatively low, the question that followed was about respecting ethical norms and their functioning in the activity of a health care institution. Here the responses were completely 
different: all managers claimed that such norms function in their institutions and all employees respect them.

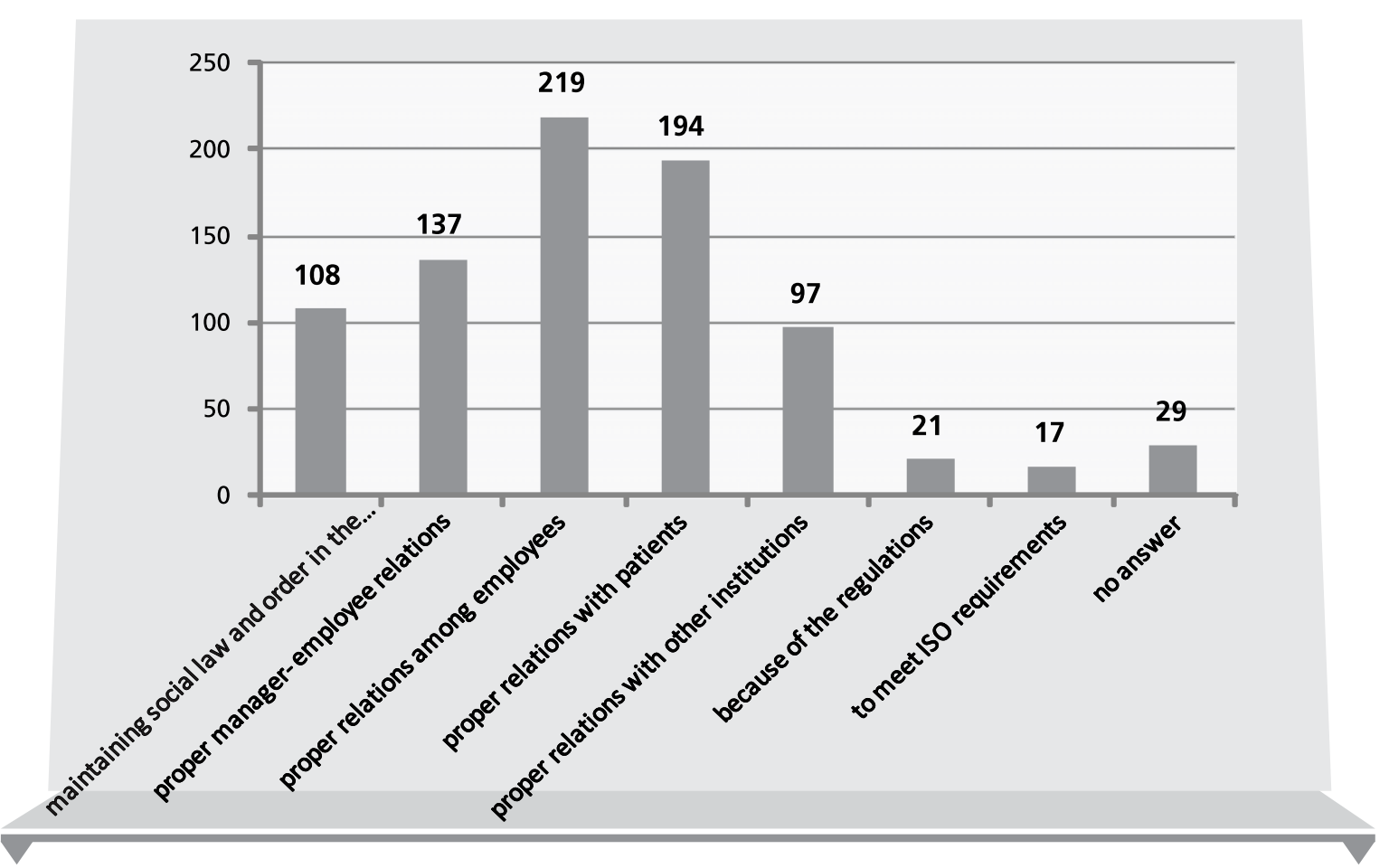

Figure 2. Purposes of introducing ethical standards into the activity of an institution

Source: own elaboration based on a questionnaire survey

It is hard to say if this answer is true, but this question led to another one, which concerned the basic purposes of introducing these norms. Here the managers' opinions differ significantly (fig. 2).

Each respondent could chose no more than three basic purposes that are to be realized according to the existing ethical standard system. Definitely the most frequent choice was the possibility to create proper relations among employees 219 responses, next were relations between employees and patients -194 . Proper manager-employee relations were marked slightly less frequently - 137, as well as the possibility of maintaining social law and order - 108, and the possibility to form proper relations with other institutions - 97 choices.

With reference to these responses one can conclude that respondents do not identify standards of ethical conduct with the concept of social responsibility, which probably results from the lack of knowledge about the concept. 
The responses to further questions were to provide knowledge about the most important effects of managing activities performed by managers. As before, respondents could choose three suggested answers, or provide their own. These responses help to find out whether managers direct their activity inside or outside the organization (fig. 3).

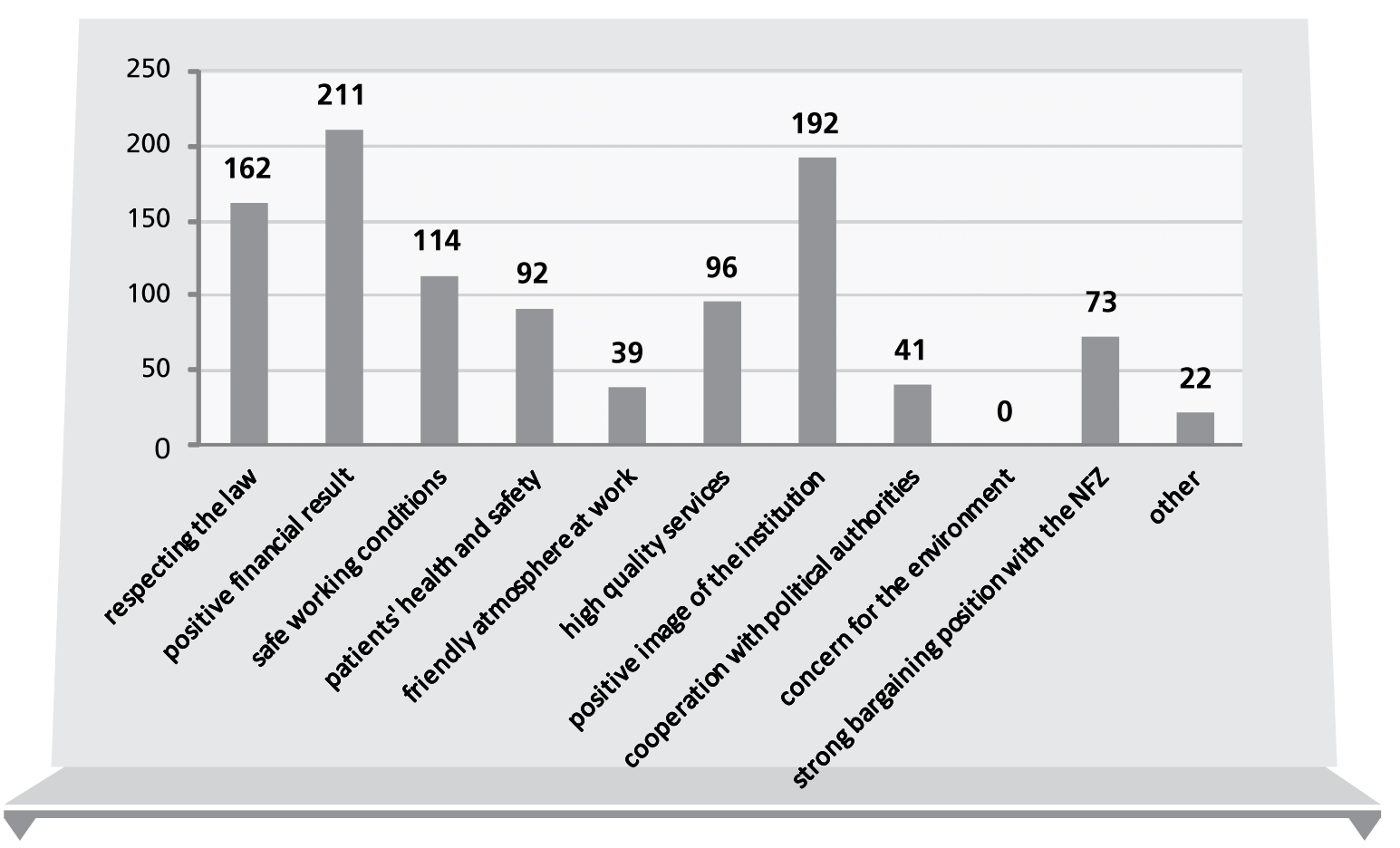

Figure 3. Expected effects of management activities performed by managers

Source: own elaboration based on a questionnaire survey

A cursory analysis is enough to notice that the policies of the surveyed health care institutions are mainly aimed at three outcomes: positive financial result 211 responses, creating a positive image in the environment - 192, and activities directed at outside stakeholders, especially patients. What is worrying is the fact that the managers indicate standard duties of an employer as important inside purposes, directed at employees, and they minimize the question of investing in human resources and creating a friendly organizational culture. What is even more surprising and worrying is that they show absolutely no concern for the natural environment where the institutions function.

Further questions aimed at determining the relation between a health care institution and its inside and outside stakeholders. That is why the managers 
were asked to indicate stakeholder groups that are the most important for them. There was a high discrepancy in the responses concerning the most important outside stakeholders according to the managers (fig.4). Patients are definitely at the top - 103, next there are institutions that cooperate with theirs - 71 . Cooperation with the NFZ - 55 and relations with the competition - 45 are at a similar level. Relations with political authorities and control institutions - 19 choices each - are the least important for the respondents.

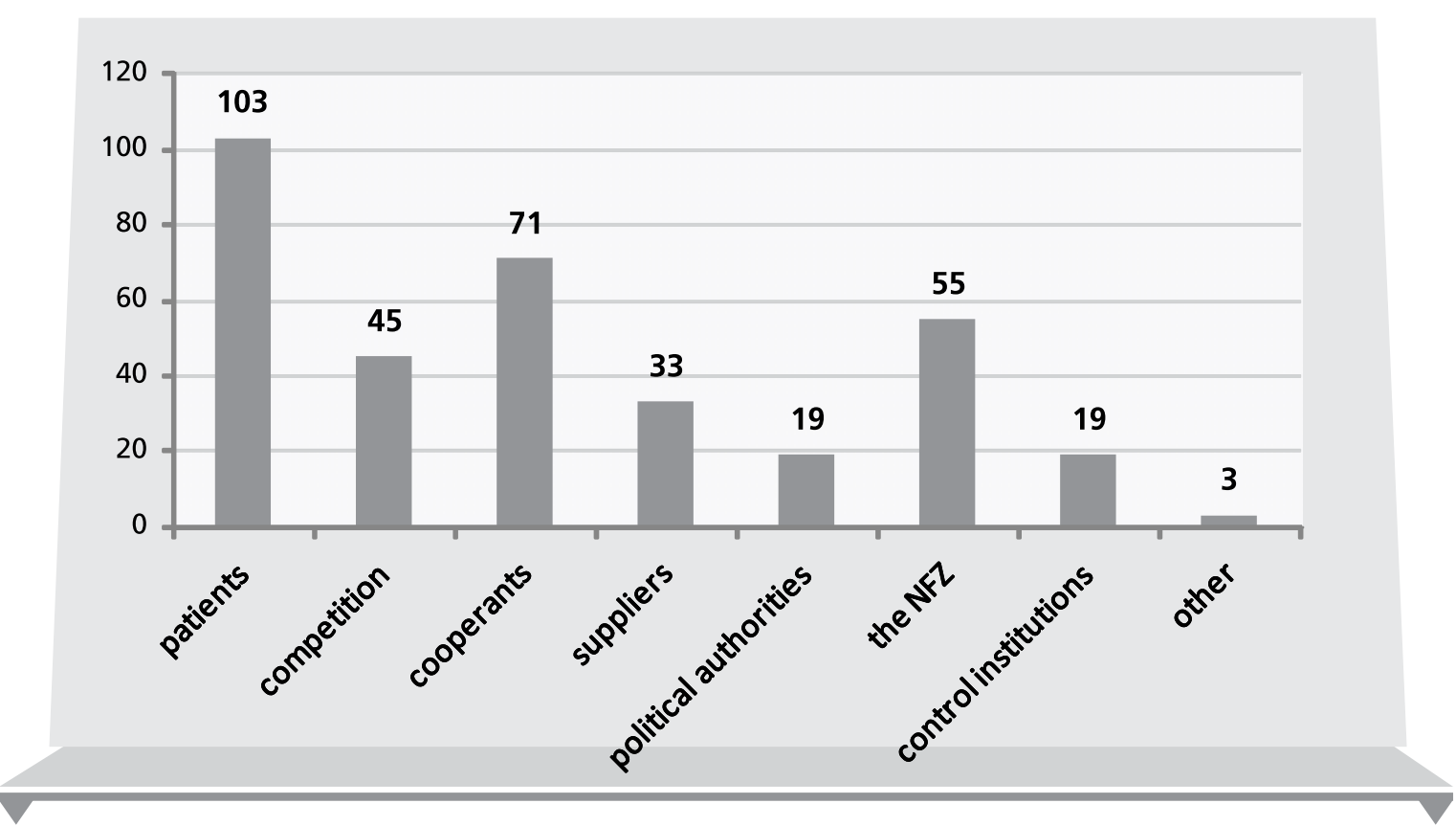

Figure 4. The most important outside stakeholder for managers

Source: own elaboration based on a questionnaire survey

Almost all respondents unanimously indicated doctors to be the most important employees - 317; only 31 indicated administrative employees; other categories of employees were completely omitted. This result is definitely worrying and can signify that almost all categories of employees apart from doctors are underestimated; this can lead to diminishing both the importance of their work and the possibility to influence the functioning of the institution.

The abovementioned responses were relatively surprising for the author, but, at the same time, they seem to be explainable. The number and type of contracted medical services, which are directly related to the amount of money 
obtained from the NFZ, depend on the number and qualifications of doctors and not other medical employees.

Nevertheless, without other employees and their involvement, it is impossible to ensure that an institution will realize its tasks properly or offer patients a satisfying level of services; therefore in the analysis of answers to subsequent questions, the author tried to determine what activities her respondents undertake to provide their employees with a friendly and safe working environment. There were two questions: How do they care for their employees? What do they do to optimally motivate their employees to work? The managers could select no more than three suggested answers, or give their own.

As for the first question, the most frequent response was providing employment that meets actual needs -217 , and salary that is adequate to qualifications -213 . Employment that meets actual needs of the organization over a long period of time and guarantees increased employment stability was indicated 162 times (fig. 5).

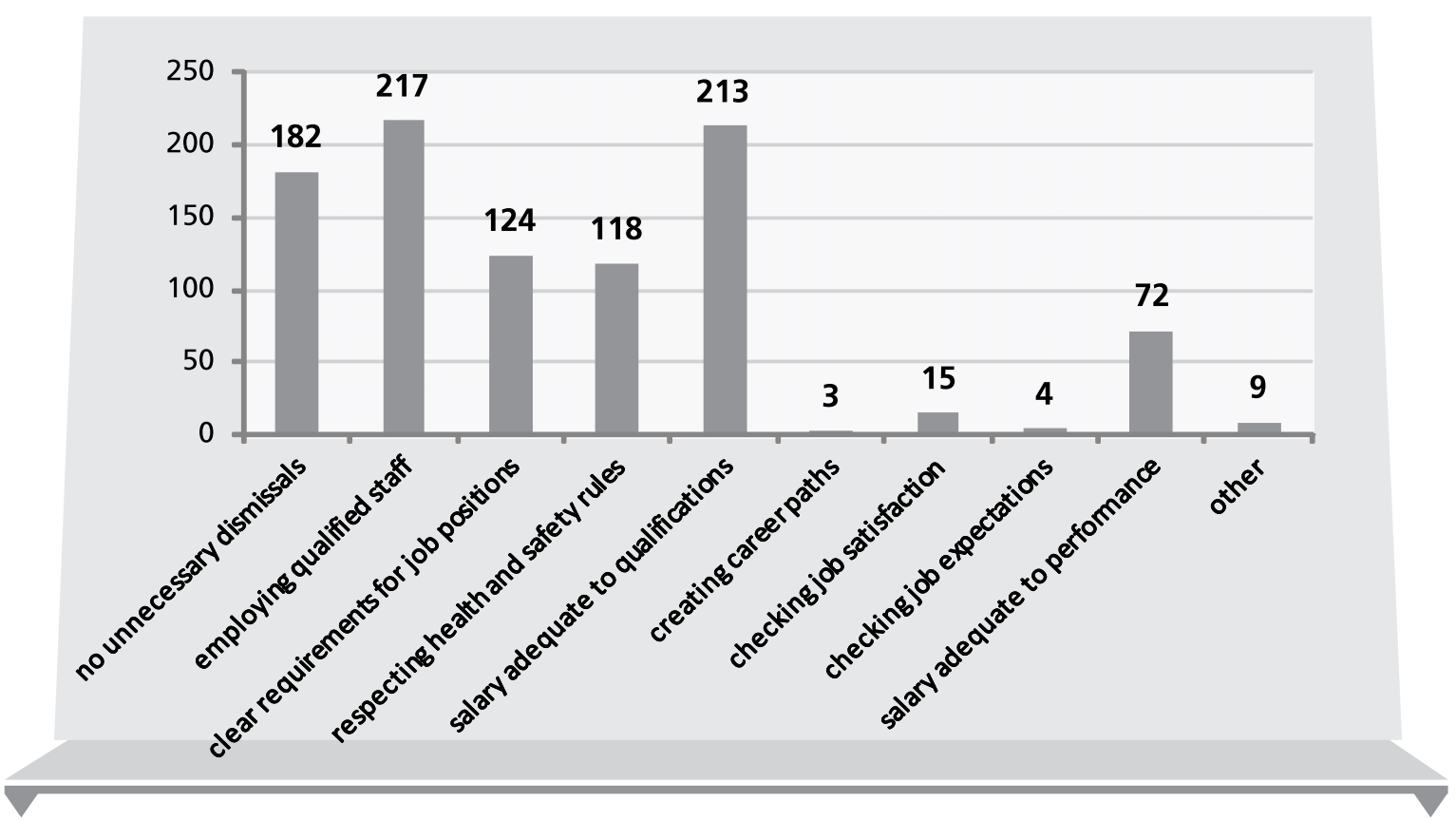

Figure 5. Manifestation of concern for employees

Source: own elaboration based on a questionnaire survey

Later there were statements about formulating clear and precise rules concerning requirements for particular job positions - 124, respecting health and 
safety rules - 118. Creating career paths, building a job satisfaction, and checking the needs and expectations connected with work were chosen sporadically.

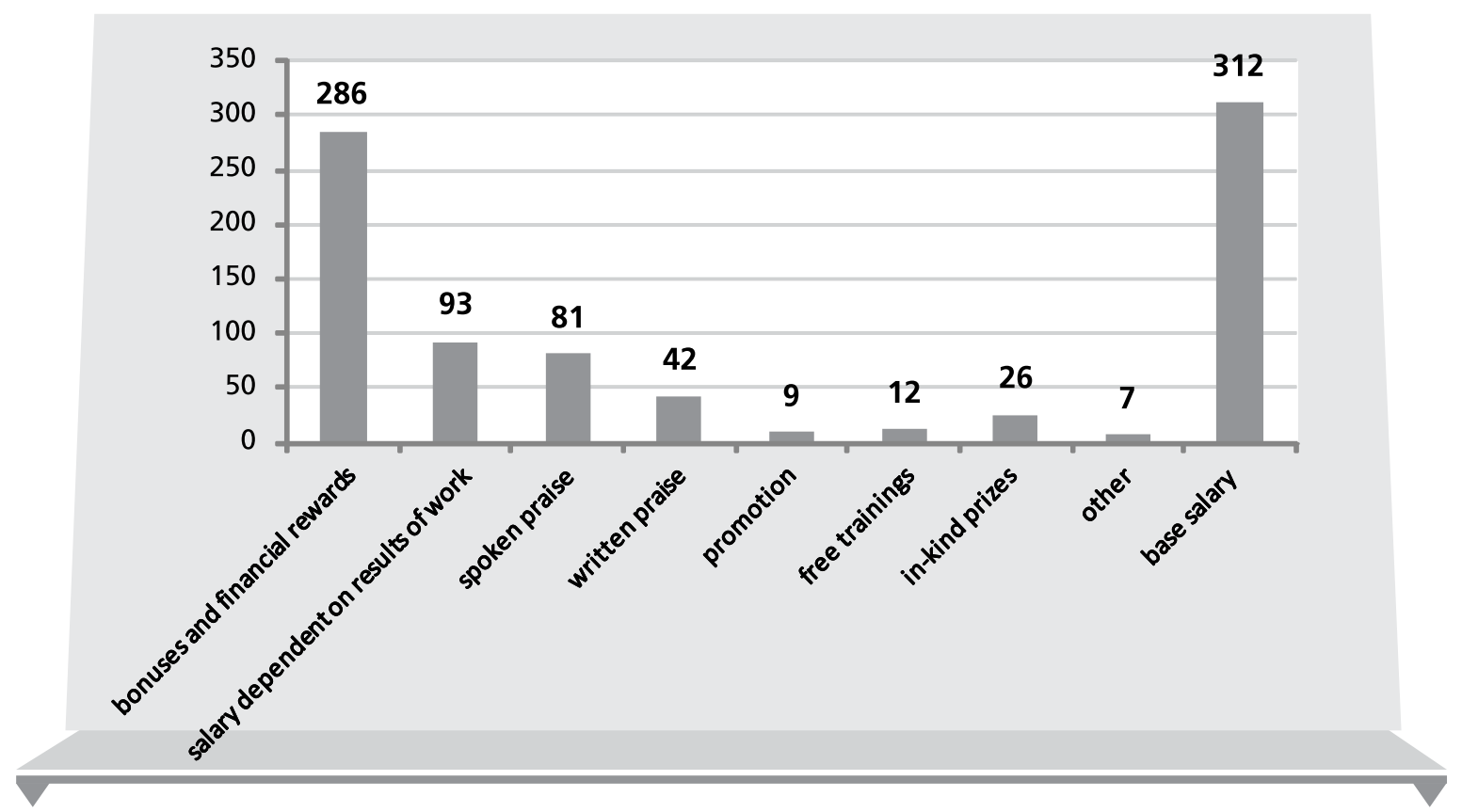

Figure 6. Ways of motivating employees by managers

Source: own elaboration based on a questionnaire survey

So again there is the pattern of thought where the dominant attitude is fulfilling obligations owed to employees rather than creating bonds and partnership relations with them. This clearly shows a lack of thinking in terms of social responsibility.

The last question in the part of the survey concerning CSR was about actions that the managers undertake to motivate their employees. Here again the predominant actions are conventional and unvaried (fig.6). Almost all respondents considered the base salary offered to employees as high enough to be motivating - 312 choices, the second most frequently selected option were bonuses and financial rewards - 286 responses. The other alternatives were chosen much less frequently or not at all. This again shows that it is a completely alien concept for managers to treat employees as stakeholders who can contribute to the development and success of their health care institution together with the management staff. 


\section{Final remarks}

The results of the research presented in the paper do not exhaust the issue as numerous problems connected with social responsibility have not been addressed. Despite the selective character of the research, however, it is possible to verify the proposed hypothesis and draw conclusions. First of all, the hypothesis has been confirmed. The managers in the surveyed health care institutions lack knowledge about CSR and are not interested in implementing the concept of social responsibility into their institution. Despite that, in some management areas one can notice that managers unconsciously take actions conforming to the CSR principles.

The survey allowed to formulate three basic conclusions:

5. The managers' lack of knowledge about CSR and their aversion to it does not automatically mean that they oppose any ethical activities in running their institutions; on the contrary - they prefer adopting such norms rather than social responsibility principles.

6. Modern health care institutions mainly concentrate on creating a positive image and concluding as many service contracts as possible, which means more customers, and not on introducing management innovations.

7. The surveyed institutions shape working conditions mainly by providing their employees with stable employment and safety at work, whereas activities concentrated on development are of little importance.

The author is fully aware that the limited scope of the research and the lack of sample representativeness do not allow to generalize the conclusions formulated here, but, at the same time, she hopes that the presented survey will inspire further work connected with diagnosing the development of the CSR concept in health care institutions in Silesia and other parts of the country.

\section{Summary:}

Social responsibility in medical subjects management

Over the years the notion of social responsibility in management was only related to economic subjects. Nowadays, a growing number of researchers is of the opinion that in managing subjects which offer social services including medical subjects, we also should implement its rules. However, it seems that in practice the knowledge of managers and employees on that subject is very limited and therefore, it has no reflection is the activities of medical subjects. 
The author of the article focuses on theoretical and practical aspects of using CSR in managing health care facilities.

Key words: Management, CSR, a manager, a medical subject.

\section{Streszczenie:}

\section{Społeczna odpowiedzialność w zarządzaniu podmiotami leczniczymi}

Przez szereg lat pojęcie społecznej odpowiedzialności w zarządzaniu odnoszono do podmiotów gospodarczych. Obecnie coraz szerzej badacze zwracają uwagę na to, że także $\mathrm{w}$ zarządzaniu podmiotami oferującymi usługi społeczne, w tym podmiotami leczniczymi, powinno się uwzględniać jej zasady. Wydaje się jednak, że w praktyce wiedza zarządzających i pracowników na ten temat jest niewielka, a tym samym nie znajduje odzwierciedlenia w działalności podmiotów leczniczych. $\mathrm{W}$ artykule autorka skupi się na teoretycznych i praktycznych aspektach wykorzystania CSR w zarządzaniu placówkami ochrony zdrowia.

Stowa

klucze: $\quad$ Zarzadzanie, CSR, menedżer, podmiot leczniczy.

\section{Bibliography:}

1. Filek J. (2008), Przyczyny matego zainteresowania idea CSR w Polsce, w: M. Bąk i P. Kulawczuk (red.), Społeczna odpowiedzialność biznesu w małych i średnich przedsiębiorstwach, Wyd. IBnDiPP, EQUAL, Warszawa.

2. Hąbek P., Pawłowska E. (2009), Społeczna odpowiedzialność organizacji a kompetencje menedżerów, „Przegląd Organizacji”, nr 2.

3. Kusa R. (2010), Spoteczna odpowiedzialność organizacji niekomercyjnych, „Ekonomia Menedżerska”, nr 7.

4. Program szkolenia w zakresie wdrażania postaw odpowiedzialności spotecznej w sektorze ochrony zdrowia i opieki społecznej (2006), Program Leonardo da Vinci, Projekt nr 1/04/B/F/PP-154095.

5. Rojek-Nowosielska M. (2006), Ksztattowanie społecznej odpowiedzialności przedsiębiorstw, Wyd. Akademii Ekonomicznej im. O. Langego, Wrocław.

6. Rok B. (2001), System społecznej odpowiedzialności biznesu, „Więcej niż zysk, czyli odpowiedzialnym biznes. Programy, strategie, standardy", Forum Odpowiedzialnego Biznesu, Warszawa. 


\section{Management \\ 2014}

Vol.18, No. 1

7. Sudoł S. (2006), Przedsiębiorstwo. Podstawy nauki o przedsiębiorstwie. Zarzadzanie przedsiębiorstwem, PWE, Warszawa.

8. Walkowiak R., Oliński M., Wysocka M., Adamowicz M. (2010), Społeczna odpowiedzialność organizacji. Praktyki na Warmii i Mazurach, Stowarzyszenie Warmińsko-Mazurska Klinika Biznesu, Olsztyn.

9. Żemigała M. (2007), Społeczna odpowiedzialność organizacji, Wolters Kluwer Polska, Kraków. 